\title{
PENEGAKAN HUKUM LINGKUNGAN DAN PENGARUHNYA TERHADAP PERTUMBUHAN EKONOMI DI INDONESIA (Studi Kebakaran Hutan Tahun 2015)
}

\author{
Suwari Akhmaddhian \\ Fakultas Hukum Universitas Kuningan \\ Email:suwariakhmaddhian@gmail.com
}

\begin{abstract}
Guarantee legal certainty and economic stability is very important to keep the movement of the economy of a country. The formulation of the problem formulated a point of issue is how the environmental law enforcement in Indonesia on a case study of forest fires in Indonesia and How to influence environmental law enforcement to economic growth in Indonesia. The purpose of this study was to determine the environmental law enforcement in Indonesia on a case study of forest fires in Indonesia and How to influence environmental law enforcement to economic growth in Indonesia. This research could be useful in a practical and theoretical. The method used by the researchers are using a normative juridical approach. The results of the study Enforcement of Environmental Law in relation to the Criminal Law which is related substance of Law in Article 69 paragraph (1) letter H Law No. 32 of 2009 on the Protection and Environmental Management includes about a ban on land clearing by burning and action against the perpetrators for enforce the law and environmental law enforcement to economic growth in Indonesia affected by three (3) aspects, namely Products of law, justice system and political risks are always changing. Conclusions of law enforcement carried out by the legislation in force and the factors that influence economic growth is necessary to be noticed is the commitment of the highest officials responsible to the reciprocation of a country. Recommendation law enforcement must be carried out according the legislation without seeing the background of the company or individual that legal certainty to invest guaranteed and the reformulation of Article 69 paragraph (1) letter H Law No. 32 of 2009 on the Protection and Environmental Management.

Keywords: Law Enforcement, Economic Growth and Its Influence.
\end{abstract}

\begin{abstract}
Abstrak
Kepastian hukum dan jaminan stabilitas ekonomi sangat penting dilakukan untuk menjaga pergerakan roda perekonomian suatu negara. Adapun rumusan masalah yang dirumuskan menjadi tititk permasalahan adalah bagaimana penegakan hukum lingkungan di Indonesia pada studi kasus kebakaran hutan di Indonesia dan Bagaimana pengaruh penegakan hukum lingkungan terhadap pertumbuhan ekonomi di Indonesia. Adapun tujuan penelitian ini adalah untuk mengetahui penegakan hukum lingkungan di Indonesia pada studi kasus kebakaran hutan di Indonesia dan Bagaimana pengaruh penegakan hukum lingkungan terhadap pertumbuhan ekonomi di Indonesia. Penelitian ini dapat berguna secara praktis dan teoritis. Metode penelitian yang digunakan oleh peneliti adalah menggunakan pendekatan yuridis normatif. Hasil penelitian Penegakan Hukum Lingkungan dalam kaitannya dengan Hukum Pidana yaitu terkait Subtansi Hukum pada Pasal 69 ayat (1) huruf H Undang-undang Nomor 32
\end{abstract}


tahun 2009 tentang Perlindungan dan Pengelolaan Lingkungan Hidup memuat tentang larangan melakukan pembukaan lahan dengan cara membakar dan tindakan terhadap pelaku untuk menegakan hukum dan Penegakan hukum lingkungan terhadap pertumbuhan ekonomi di Indonesia terpengaruhi oleh 3 (tiga) Aspek yaitu Produk hukum, Sistem Hukum dan Resiko politik yang selalu berubah. Kesimpulan penegakan hukum dilakukan berdasarkan peraturan perundang-undangan yang berlaku dan faktor-faktor yang mempengaruhi pertumbuhan ekonomi yang sangat perlu di perhatikan adalah komitmen pejabat tertinggi yang bertangung jawab terhadap maju mundurnya suatu negara. Rekomendasi penegakan hukum harus dilakukan sesuai peraturan perundang-undangan tanpa melihat latar belakang perusahaan atau individu sehingga kepastian hukum untuk berinvestasi terjamin dan reformulasi Pasal 69 ayat (1) huruf H Undang-undang Nomor 32 tahun 2009 tentang Perlindungan dan Pengelolaan Lingkungan Hidup.

Kata kunci : Penegakan Hukum, Pertumbuhan Ekonomi dan Pengaruhnya.

\section{A. Pendahuluan}

Penegakan hukum merupakan isu yang menarik untuk diteliti karena berkaitan dengan implementasi peraturan perundangundangan yang berlaku, penegakan hukum lingkungan sangat berkaitan dengan semua aspek kehidupan manusia karena lingkungan merupakan penyangga kehidupan mahluk hidup di bumi ini. Secara konstitisonal terdapat dalam Pasal 28 huruf $h$ ayat (1) yang berbunyi "setiap orang hidup sejahtera lahir dan batin, bertempat tinggal dan mendapatkan lingkungan hidup yang baik dan sehat serta memperoleh pelayanan kesehatan" dan Pasal 33 ayat (3) yang berbunyi "Bumi dan air dan kekayaan alam yang terkandung di dalamnya dikuasai oleh negara dan dipergunakan untuk sebesarbesar kemakmuran rakyat" pada pasal 28 dikatakan setiap warga negara berhak akan lingkungan yang baik dan sehat, penegakan hukum lingkungan merupakan instrumen untuk menciptakan lingkungan yang baik dan sehat ${ }^{1}$.

${ }^{1}$ Suwari Akhmaddhian, 2013, "Peran Pemerintah Daerah dalam Mewujudkan Hutan Konservasi Berdasarkan Undang-Undang Nomor 41 Tahun 1999 Tentang Kehutanan 
Peraturan perundang-undangan yang berkaitan dengan lingkungan hidup yaitu Undang-undang Nomor 32 Tahun 2009 tentang Perlindungan dan Pengelolaan Lingkungan Hidup, UndangUndang Nomor 05 Tahun 1990 tentang Konservasi Sumberdaya Alam Hayati dan Ekosistemnya, Undang-Undang Nomor 41 Tahun 1999 tentang Kehutanan. Undang-undang Nomor 32 Tahun 2009 tentang Perlindungan dan Pengelolaan Lingkungan Hidup mengatur sanksi kepada pihak yang terbukti melanggar yaitu penegakan hukum dibidang lingkungan hidup dapat diklasifikasikan kedalam 3 (tiga) kategori yaitu : 1). Penegakan hukum Lingkungan dalam kaitannya dengan Hukum Administrasi / Tata Usaha Negara, 2). Penegakan Hukum Lingkungan dalam kaitannya dengan Hukum Perdata, 3). Penegakan Hukum Lingkungan dalam kaitannya dengan Hukum Pidana.

Permasalahan utama dalam lingkungan hidup yang teridentifikasi ada 5 (lima) antara $\left.\operatorname{lain}^{2}: 1\right)$ kerusakan lahan akibat penggundulan hutan, penebangan liar, alih fungsi lahan untuk perkebunan dan tanaman industri, penambangan minyak, industri dan permukiman; 2) abrasi pinggir sungai akibat laluintas pelayaran kapal-kapal besar dan cepat; 3) pendangkalan sungai oleh tingginya erosi, abrasi dan sedimentasi; 4) gangguan pola aliran air permukaan akibat alih fungsi lahan, keberadaan pelabuhan, dermaga, dan logpond; 5) penurunan kualitas air akibat buangan limbah cair industri, domestik

(Studi di Kabupaten Kuningan)", Jurnal Dinamika Hukum . Vol. 13 No.3 September 2013, Purwokerto: FH Unsoed, hlm. 446-556

${ }^{2}$ Nana Sudiana dan Hasmana Soewandita, 2007, Pola Konservasi Sumber Daya Air di Daerah Aliran Sungai Siak, Jurnal Alami Vol. 12 Nomor 1, Halaman. 44-51. 
pembuangan air ballast kapal, dan buangan limbah padat domestik.

Maka dengan adanya penelitian ini diharapkan dapat mengukur dan mengetahui sejauh mana implementasi penegakan hukum lingkungan di kabupaten kuningan dan dalam upaya mendukung kuningan sebagai kabupaten konservasi sesuai dengan harapan dan diharapkan hasil penelitian ini dijadikan landasan dan acuan dari pihak terkait dalam membuat atau memperbaiki kebijakan yang terkait konservasi di kabupaten kuningan. Masalah lingkungan hidup ini dapat ditinjau dari aspek medik, planologis teknologis, teknik lingkungan, ekonomi dan hukum. Hal ini dikemukakan oleh Siti Sundari Rangkuti yaitu segi-segi hukum pengelolaan lingkungan hidup dan konservasi sumber daya alam di Indonesia perlu dikaji secara intensif, karena pengelolaan lingkungan tidak mungkin tanpa pengaturan hukum. Hal ini tidak berarti bahwa ahli hukum dapat menangani masalah lingkungan terlepas dari disiplin ilmu lain yang berkaitan dengan bidang lingkungan hidup ${ }^{3}$.

\section{B. Rumusan Masalah}

Berkaitan dengan latar belakang yang telah diuraikan di atas, maka rumusan masalah dalam tulisan ini dirumuskan sebagai berikut: 1. Bagimana penegakan hukum lingkungan di Indonesia pada studi kasus kebakaran hutan.?

\footnotetext{
${ }^{3}$ Siti Kotijah, 2010, Implementasi Prinsip-prinsip Kehutanan dalam Rangka Konservasi Kehutanan: studi kasus di Jawa Timur, Jurnal Magister Hukum, Vol. 1 Nomor 2, Surabaya : Program Studi Magister Ilmu Hukum, Universitas Wisnuwardhana, Halaman. 354-386
} 
2. Bagaimana pengaruh penegakan hukum lingkungan terhadap pertumbuhan ekonomi di Indonesia.?

\section{Metode Penelitian}

Penelitian yang digunakan oleh penulis adalah yuridis normatif (doktrinal). Data yang digunakan dalam penelitian ini adalah data sekunder yaitu bahan hukum primer mulai dari UUD 1945, Undangundang Nomor 32 Tahun 2009 tentang Perlindungan dan Pengelolaan Lingkungan Hidup dan dan Undang-undang Nomor 18 Tahun 2013 tentang Pencegahan dan Pemberantasan Perusakan Hutan, bahan hukum sekunder berupa jurnal, penelitian-penelitain terdahulu serta buu referensi yang relevan. Metode penelitian hukum, menurut Soerjono Soekanto adalah " suatu kegiatan ilmiah, yang di dasarkan pada metode, sistematika dan pemikiran tertentu, yang bertujuan mempelajari satu atau beberapa gejala hukum tertentu, dengan menganalisanya .

\section{Pembahasan}

1. Penegakan Hukum Lingkungan di Indonesia Studi Kasus

\section{Kebakaran Hutan}

Definisi penegakan hukum menurut Kamus Besar Bahasa Indonesia (KBBI) memiliki arti yang sangat luas meliputi segi preventif dan represif, cocok dengan kondisi Indonesia yang unsur pemerintahnya turut aktif dalam meningkatkan kesadaran hukum masyarakat. Penegakan hukum menurut Satjipto Rahardjo, merupakan suatu proses untuk mewujudkan keinginan-keinginan hukum menjadi kenyataan. ${ }^{4}$ Keinginan-keinginan hukum yang

\footnotetext{
${ }^{4}$ Satjipto Rahardjo, 1983, Masalah Penegakan Hukum, Bandung: Sinar Baru, hal. 24
} 
dimaksudkan di sini yaitu yang merupakan pikiran-pikiran badan pembentuk undang-undang yang dirumuskan dalam peraturanperaturan hukum itu. Perumusan pikiran pembuat hukum yang dituangkan dalam peraturan hukum, turut menentukan bagaimana penegakan hukum itu dijalankan. Dengan demikian pada gilirannya, proses penegakan hukum itu memuncak pada pelaksanaannya oleh para pejabat penegak hukum itu sendiri. Dari keadaan ini, dengan nada ekstrim dapat dikatakan bahwa keberhasilan ataupun kegagalan para penegak hukum dalam melaksanakan tugasnya sebetulnya sudah dimulai sejak peraturan hukum yang harus dijalankan itu dibuat. ${ }^{5}$ Proses penegakan hukum, dalam pandangan Soerjono Soekanto, dipengaruhi oleh 5 (lima) faktor 6 . Pertama, faktor hukum atau peraturan perundangundangan. Kedua, faktor aparat penegak hukumnya, yakni pihak-pihak yang terlibat dalam peroses pembuatan dan penerapan hukumnya, yang berkaitan dengan masalah mentalitas. Ketiga, faktor sarana atau fasilitas yang mendukung proses penegakan hukum. Keempat, faktor masyara-kat, yakni lingkungan social di mana hukum tersebut berlaku atau diterapkan; berhubungan dengan kesadaran dan kepatuhan hukum yang merefleksi dalam perilaku masyarakat. Kelima, faktor kebudayaan, yakni hasil karya, cipta dan rasa yang didasarkan pada karsa manusia di dalam pergaulan hidup.

Sementara itu Satjipto Rahardjo, membedakan berbagai unsur yang berpengaruh dalam proses penegakan hukum berdasarkan derajat kedekatannya pada proses, yakni yang agak

\footnotetext{
${ }^{5}$ Ibid, hal. 25

${ }^{6}$ Soerjono Soekanto, 1983, Penegakan Hukum, Jakarta: BPHN \& Binacipta, hal. 15
} 
jauh dan yang agak dekat. Berdasarkan criteria kedekatan tersebut, maka Satjipto Rahardjo membedakan 3 (tiga) unsur utama yang terlibat dalam proses penegakan hukum ${ }^{7}$. Pertama, unsur pembuatan undang-undang cq. lembaga legislatif. Kedua, unsur penegakan hukum cq. polisi, jaksa dan hakim. Dan ketiga, unsur lingkungan yang meliputi pribadi warga negara dan sosial. Pada sisi lain, Jerome Frank, juga berbicara tentang berbagai faktor yang turut terlibat dalam proses penegakan hukum. Beberapa faktor ini selain faktor kaidah-kaidah hukumnya, juga meliputi prasangka politik, ekonomi, moral serta simpati dan antipati pribadi ${ }^{8}$. Sementara itu, Lawrence M. Friedman melihat bahwa keberhasilan penegakan hukum selalu menyaratkan berfungsinya semua komponen system hukum. Sistem hukum dalam pandangan Friedman terdiri dari tiga komponen', yakni komponen struktur hukum (legal structure), komponen substansi hukum (legal substance) dan komponen budaya hukum (legal culture). Struktur hukum (legal structure) merupakan batang tubuh, kerangka, bentuk abadi dari suatu sistem. Substansi hukum (legal substance) aturan-aturan dan norma-norma actual yang dipergunakan oleh lembaga-lembaga, kenyataan, bentuk perilaku dari para pelaku yang diamati di dalam sistem. Adapun kultur atau budaya hukum (legal culture) merupakan gagasan-gagasan, sikap-sikap, keyakinan-keyakinan, harapan-

\footnotetext{
7 Satjipto Rahardjo,1983, Masalah Penegakan Hukum ,Bandung: Sinar Baru, hal. 23,24

${ }^{8}$ Lili Rasjidi, 1991, Filsafat Hukum Apakah Hukum Itu?, Bandung: Remaja Rosdakarya, hal. 51.

${ }^{9}$ Lawrence M. Friedman, 1984, American Law: An invalueable guide to the many faces of the law, and how it affects our daily lives, New York: W.W. Norton \& Company, hal 16.
} 
harapan dan pendapat tentang hukum. Dalam perkembangan-nya, Friedman menambahkan pula komponen yang keempat, yang disebutnya komponen dampak hukum (legal impact). Dengan komponen dampak hukum ini yang dimaksudkan adalah dampak dari suatu keputusan hukum yang menjadi objek kajian peneliti. Berkaitan dengan budaya hukum (legal culture) ini, menurut Roger Cotterrell, konsep budaya hukum itu menjelaskan keanekaragaman ide tentang hukum yang ada dalam berbagai masyarakat dan posisinya dalam tatanan sosial. Ide-ide ini menjelaskan tentang praktik-praktik hukum, sikap warga Negara terhadap hukum dan kemauan dan ketidakmauannya untuk mengajukan perkara, dan signifikansi hukum yang relatif, dalam menjelaskan pemikiran dan perilaku yang lebih luas di luar praktik dan bentuk diskursus khusus yang terkait dengan lembaga hukum. Dengan demikian, variasi budaya hukum mungkin mampu menjelaskan banyak tentang perbedaan-perbedaan cara di mana lembaga hukum yang nampak sama dapat berfungsi pada masyarakat yang berbeda ${ }^{10}$. Substansi hukum dalam wujudnya sebagai peraturan perundang-undangan, telah diterima sebagai instrumen resmi yang memeproleh aspirasi untuk dikembangkan, yang diorientasikan secara pragmatis untuk menghadapi masalah-masalah sosial yang kontemporer. Hukum dengan karakter yang demikian itu lebih dikenal dengan konsep hukum law as a tool of social engineering dari Roscoe Pound, atau yang di dalam terminologi Mochtar Kusumaatmadja disebutkan sebagai hukum yang berfungsi sebagai sarana untuk membantu

10 Mochtar Kusumaatmadja, 1986, Fungsi dan Perkembangan Hukum dalam Pembangunan Nasional, Bandung: Binacipta, hal. 11. 
perubahan masyarakat. ${ }^{11}$ Karakter keberpihakan hukum yang responsif ini, sering disebutkan sebagai hukum yang emansipatif. Hukum yang emansipatif mengindikasikan sifat demokratis dan egaliter, yakni hukum yang memberikan perhatian pada upaya memberikan perlindungan hak-hak asasi manusia dan peluang yang lebih besar kepada warga masyarakat yang lemah secara sosial, ekonomi dan politis untuk dapat mengambil peran partisipatif dalam semua bidang kehidupan bermasyarakat, berbangsa dan bernegara. Dikatakan bahwa hukum yang responsif terdapat di dalam masyarakat yang menjunjung tinggi semangat demokrasi. Hukum responsif menampakkan ciri bahwa hukum ada bukan demi hukum itu sendiri, bukan demi kepentingan praktisi hukum, juga bukan untuk membuat pemerintah senang, melainkan hukum ada demi kepentingan rakyat di dalam masyarakat. ${ }^{12}$

Berkaitan dengan karakter dasar hukum positif ini, Sunaryati Hartono melihat bahwa Undang-Undang Dasar 1945 disusun dengan lebih berpegang pada konsep hukum sebagai sarana rekayasa sosial ini $^{13}$. Karakter hukum positif dalam wujudnya sebagai peraturan peraturan perundang-undangan, di samping ditentukan oleh suasana atau konfigurasi politik momentum pembuatannya, juga berkaitan erat dengan komitmen moral serta profesional dari para anggota legislatif itu sendiri. Oleh karena semangat hukum (spirit of law) yang dibangun berkaitan erat dengan visi pembentuk undang-

\footnotetext{
${ }^{11}$ Ibid, hal. 18.

${ }^{12}$ Max Weber dalam A.A.G. Peters dan Koesriani Siswosoebroto, 1988, Hukum dan Perkembangan Sosial (Buku I), Jakarta: Sinar Harapan, hal. 483

${ }^{13}$ C.F.G. Sunaryati Hartono, 1991, Politik Hukum Menuju Satu Sistem Hukum Nasional, Bandung: Alumni, hal. 53.
} 
undang, maka dalam konteks membangun hukum yang demokratis, tinjauan tentang peran pembentuk undang-undang penting dilakukan. Dikemukakan oleh Gardiner bahwa pembentuk undang-undang tidak semata-mata berkekewajiban to adapt the law to this changed society, melainkan juga memiliki kesempatan untuk memberikan sumbangan terhadap pembentukan perubahan masyarakat itu sendiri. Pembentuk undang-undang, dengan demikian, tidak lagi semata-mata mengikuti perubahan masyarakat, akan tetapi justru mendahului perubahan masyarakat itu. Dalam kaitan ini Roeslan Saleh menegaskan bahwa masyarakat yang adil dan makmur serta modern yang merupakan tujuan pembangunan bangsa, justru sesungguhnya merupakan kreasi tidak langsung dari pembentuk undang-undang. ${ }^{14}$

Istilah penegakan hukum dalam Bahasa Indonesia membawa kita kepada pemikiran bahwa penegakan hukum selalu dengan paksaan sehingga ada yang berpendapat bahwa penegakan hukum hanya bersangkutan dengan hukum pidana saja. Penegakan hukum memiliki arti yang sangat luas meliputi segi preventif dan represif, cocok dengan kondisi Indonesia yang unsur pemerintahnya turut aktif dalam meningkatkan kesadaran hukum masyarakat. Secara konsepsional, maka inti dan arti penegakan hukum terletak pada kegiatan menyerasikan hubungan nilai-nilai yang terjabarkan di dalam kaidah-kaidah yang mantap dan sikap tindak sebagai rangkaian penjabaran nilai tahap akhir untuk menciptakan, memelihara dan mempertahankan kedamaian pergaulan hidup.

14 Roeslan Saleh, 1979, Penjabaran Pancasila dan UUD 1945 Dalam Perundangundangan, Jakarta: Bina Aksara, hal. 12 
Penegakan hukum lingkungan merupakan penegakan hukum yang cukup rumit karena hukum lingkungan menempati titik silang antara antara berbagai bidang hukum klasik.

Penegakan hukum lingkungan merupakan mata rantai terakhir dalam siklus pengaturan perencanaan kebijakan tentang lingkungan yang urutannya sebagai berikut: 1.). Perundang-undangan, 2). Penentuan standar, 3). Pemberian izin, 4). Penerapan, 5). Penegakan hukum. Menurut Mertokusumo, kalau dalam penegakan hukum, yang diperhatikan hanya kepastian hukum, maka unsur-unsur lainnya dikorbankan. Demikian pula kalau yang diperhatikan hanyalah kemanfaatan, maka kepastian hukum dan keadilan dikorbankan. Oleh karena itu dalam penegakan hukum lingkungan ketiga unsur tersebut yaitu kepastian, kemanfaatan, dan keadilan harus dikompromikan. Artinya ketiganya harus mendapat perhatian secara proposional seimbang dalam penanganannya, meskipun di dalam praktek tidak selalu mudah melakukannya. Berbeda halnya dengan M. Daud Silalahi yang menyebutkan bahwa penegakan hukum lingkungan mencakup penaatan dan penindakan yang meliputi hukum administrasi negara, bidang hukum perdata dan bidang hukum pidana. Undang-Undang No.32 Tahun 2009 tentang Perlindungan dan Pengelolaan Lingkungan Hidup menyediakan tiga macam penegakan hukum lingkungan yaitu penegakan hukum administrasi, perdata dan pidana. Diantara ke tiga bentuk penegakan hukum yang tersedia, penegakan hukum administrasi dianggap sebagai upaya penegakan hukum terpenting. Hal ini karena penegakan hukum administrasi lebih ditunjukan kepada upaya mencegah terjadinya pencemaran dan perusakan 
lingkungan. Di samping itu, penegakan hukum administrasi juga bertujuan untuk menghukum pelaku pencemaran dan perusakan lingkungan. Penegakan hukum adalah proses dilakukannya upaya tegaknya atau berfungsinya norma-norma hukum secara nyata sebagai pedoman perilaku dalam hubungan-hubungan dalam kehidupan bermasyarakat dan bernegara. Ditinjau dari subyeknya, penegakan hukum dapat dilakukan oleh subyak yang luas dan dapat pula diartikan sebagai upaya penegakan hukum itu melibatkan semua subyek hukum dalam setiap hubungan hukum.menurut subyeknya penegakan hukum dapat diartikan sebagai upaya aparatur penegak hukum tertentu untuk menjamin dan memastikan tegaknya hukum itu dan aparatur penegak hukum itu dapat menggunakan daya paksa untuk dalam proses penegakan hukum. ${ }^{15}$ Adi Sulistyono memberikan berpendapat mengenai konsep pembangunan pembangunan hukum ekonomi berkelanjutan (sustainable economic law development), selain melakukan pembangunan hukum harus memberdayakan daya dukung aspek yang lainnya ${ }^{16}$ :

a. Pendidikan hukum,

b. Reformasi Subtanasi hukum;

c. Mekanisme penyelesaian sengketa yang berwibawa dan efisien;

d. Pemberdayaan etika bisnis;

e. Menumbuhkan jiwa nasionalis pada anggota Legislatif;

f. Komitmen presiden dan wakil presiden, yang aktivitasnya dilakukan secara mengait, bersama-sama, dan terus menerus dan saling mendukung.

\footnotetext{
${ }^{15}$ Kartono, 2009, Penegakan Hukum Lingkungan Administratif Dalam Undang-Undang Perlindungan dan Pengelolaan Lingkungan Hidup, Jurnal Dinamika Hukum, Vol.09 No. 3, Purwekerto: FH UNSOED, halaman 247-257.

${ }^{16}$ Adi Sulistyono dan Muhammad Rastamji, 2009, Hukum Ekonomi Sebagai Panglima, Masmedia Buana Pustaka, Sidoarjo, halaman 75.
} 
Hukum merupakan sarana yang didalamnya terkandung nilai-nilai atau konsep-konsep tentang keadilan, kebenaran, kemanfaatan sosial dan sebagainya. Kandungan hukum itu bersifat abstrak. Menurut Satjipto Raharjo sebagaimana dikutip oleh Ridwan HR, penegakan hukum pada hakikatnya merupakan penegakan ide-ide atau konsep-konsep yang abstrak itu. Penegakan hukum merupakan usaha untuk mewujudkan ide-ide tersebut menjadi kenyataan. ${ }^{17}$

Menurut Soerjono Soekanto bahwa penegakan hukum itu terletak pada suatu kegiatan yang menyerasikan hubungan dari nilai-nilai yang terjabarkan di dalam kaidah-kaidah/pandanganpandangan nilai yang mantap dan mengejewantah dan sikap tindak sebagai rangkaian penjabaran nilai tahap akhir untuk menciptakan (sebagai social engineering), memelihara dan mempertahankan (sebagai social control) kedamaian pergaulan hidup. $^{18}$

Menurut Soerjono Soekanto secara umum ada 5 (lima) faktor yang mempenguruhi penegakan hukum yaitu: ${ }^{19}$

a. Faktor hukum itu sendiri;

b. Faktor penegak hukum yaitu pihak-pihak yang membentuk maupun yang menerapkan hukum

c. Faktor sarana atau fasilitas yang mendukung penegakan hukum

d. Faktor masyarakat, yakni lingkungan dimana hukum tersebut berlaku atau diterapkan;

\footnotetext{
${ }^{17}$ Ridwan HR. Hukum administrasi Negara. PT.RajaGrafindo. Jakarta. 2006. hal. 306

${ }^{18}$ Soerjono Soekanto. Faktor-Faktor Yang Penegakan Hukum. Jakarta. Bina Cipta. 1983. hal. 13.

${ }^{19}$ Soerjono Soekanto. Faktor-faktor yang mempengaruhi Penegakan Hukum. Rajawali Press. 1983. Jakarta. hal. 4-5.
} 
e. Faktor kebudayaan, yakni sebagai hasil karya, cipta dan rasa yang didasarkan pada karsa manusia di dalam pergaulan hidup.

Kelima faktor tersebut diatas saling berkaitan dengan eratnya, karena merupakan esensi dari penegakan hukum serta merupakan tolok ukur dari pada efektifitas penegakan hukum. Menurut Mertokusumo sebagaimana dikutiop oleh Gatot. P. Soemartono Penegakan hukum mempunyai makna, bagaimana hukum itu harus dilaksanakan, sehingga dalam penegakan hukum tersebut harus diperhatikan unsur-unsur 1. kepastian hukum, 2. kemanfaatan, 3. keadilan. ${ }^{20}$

a. Kepastian hukum menghendaki bagaimana hukumnya dilaksanakan, tanpa peduli bagaimana pahitnya (fiat justitia et pereat mundus : meskipun dunia ini runtuh hukum harus ditegakkan). Hal ini dimaksudkan agar tercipta ketertiban dalam masyarakat. Misalnya "Barang siapa mencemarkan lingkungan maka ia harus dihukum," ketentuan ini menghendaki agar siapapun (tidak peduli jabatannya) apabila melakukan perbuatan pencemaran lingkungan maka ia harus dihukum.

b. Pelaksanaan penegakan hukum harus memberi manfaat kepada masyarakat. Artinya peraturan tersebut dibuat adalah untuk kepentingan masyarakat, sehingga jangan sampai terjadi bahwa karena dilaksanakannya peraturan tersebut, masyarakat justru menjadi resah. Contoh sebuah pabrik konveksi yang mempekerjakan ribuah orang ditutup karena ia

${ }^{20}$ Gatot. P. Soemartono. Hukum Lingkungan Indonesia. Jakarta. Sinar Grafika. hal. 65. 
telah mencemarkan lingkungan, hal ini tentu akan menimbulkan keresahan baik masyarakat dunia usaha maupun para pekerjanya. Mengapa tidak dicari jalan keluarnya, misalnya menyeret pengelola perusahaan tersebut ke Pengadilan, mewajibkan membayar pemulihan lingkungan, tetapi kegiatan pabrik tetap berjalan dengan pengawasan ketat disertai pengurangan produksi. Inilah yang disebut dengan kemanfaatan dalam penegakan hukum lingkungan.

c. Unsur ketiga adalah keadilan. Dalam penegakan hukum keadilan harus diperhatikan, namun demikian hukum tidak identik dengan keadilan, karena hukum sifatnya umum, mengikat setiap orang, dan menyamaratakan : bunyi hukum: Barang siap mencemarkan lingkungan hidup harus dihukum", artinya setiap orang yang mencemarkan lingkumgan harus dihukum tanpa membeda-bedakan kedudukan atau jabatan siapa yang mencemarkan. Tetapi sebaliknya, keadilan bersifat subjektif, individualistis dan menyamaratakan, artinya adil bagi si $A$ belum tentu adil bagi si B, pencemar yang dimenangkan akan mengatakan bahwa keputusan tersebut adil, tetapi hal itu tentu dirasakan tidak adil bagi si korban.

Dari uraian tersebut dapat disimpulkan, bahwa tanpa kepastian orang tidak tahu apa yang harus diperbuatnya dan akhirnya timbul keresahan. Tetapi apabila kita terlalu mengejar kepastian hukum, terlalu ketat dalam mentaati peraturan hukum akibatnya akan menjadi kaku dan akan menimbulkan rasa tidak adil. Kalau dalam penegakan hukum hanya memperhatikan 
kepastian hukum, maka unsur-unsur lainnya akan dikorbankan. Demikian pula kalau yang diperhatikan hanyalah kemanfaatan, maka kepastian hukum dan keadilan dikorbankan, demikian seterusnya. Oleh karena itu dalam penegakan hukum lingkungan ketiga unsur tersebut, yaitu kepastian, kemanfaatan dan keadilan harus dikompromikan. Artinya ketiganya harus mendapat perhatian secara proposional seimbang dalam penanganannya, meskipun dalam praktek tidak selalu mudah melakukannya.

Undang-undang Nomor 32 Tahun 2009 tentang Perlindungan dan Pengelolaan Lingkungan Hidup mengatur sanksi kepada pihak yang terbukti melanggar yaitu penegakan hukum dibidang lingkungan hidup dapat diklasifikasikan kedalam 3 (tiga) kategori yaitu: 1). Penegakan hukum Lingkungan dalam kaitannya dengan Hukum Administrasi / Tata Usaha Negara, 2). Penegakan Hukum Lingkungan dalam kaitannya dengan Hukum Perdata, 3). Penegakan Hukum Lingkungan dalam kaitannya dengan Hukum Pidana. Pada Pasal 69 ayat (1) huruf H Undang-undang Nomor 32 tahun 2009 tentang Perlindungan dan Pengelolaan Lingkungan Hidup memuat tentang larangan melakukan pembukaan lahan dengan cara membakar yaitu: (1) Setiap orang dilarang: $h$. melakukan pembukaan lahan dengan cara membakar; Pasal 108 Undang-undang Nomor 32 tahun 2009 tentang Perlindungan dan Pengelolaan Lingkungan Hidup memuat tentang sanksi bagi yang melanggar yaitu: Setiap orang yang melakukan pembakaran lahan sebagaimana dimaksud dalam Pasal 69 ayat (1) huruf $h$, dipidana 
dengan pidana penjara paling singkat 3 (tiga) tahun dan paling lama 10 (sepuluh) tahun dan denda paling sedikit Rp3.000.000.000,00 (tiga miliar rupiah) dan paling banyak Rp10.000.000.000,00 (sepuluh miliar rupiah). Penegakan hukum lingkungan di Indonesia di lakukan oleh pemerintah dengan tegas yaitu terbukti Kejagung Terima 126 Surat Penyidikan Kasus Kebakaran Hutan, Kejaksaan Agung sampai sekarang sudah menerima 126 Surat Pemberitahuan Dimulainya Penyidikan (SPDP) kasus kebakaran hutan dan lahan di seluruh Indonesia dari kepolisian, ini menandakan bahwa kepastian hukum, kemanfaatan dan keadilan harus tercapai sebagai tujuan dari hukum itu sendiri ${ }^{21}$.

Penegakan hukum lingkungan merupakan mata rantai terakhir dalam siklus pengaturan perencanaan kebijakan tentang lingkungan yang urutannya sebagai berikut: 1.). Perundangundangan, 2). Penentuan standar, 3). Pemberian izin, 4). Penerapan, 5). Penegakan hukum. Menurut Mertokusumo, kalau dalam penegakan hukum, yang diperhatikan hanya kepastian hukum, maka unsur-unsur lainnya dikorbankan. Demikian pula kalau yang diperhatikan hanyalah kemanfaatan, maka kepastian hukum dan keadilan dikorbankan. Oleh karena itu dalam penegakan hukum lingkungan ketiga unsur tersebut yaitu kepastian, kemanfaatan, dan keadilan harus dikompromikan. Artinya ketiganya harus mendapat perhatian secara proposional

${ }^{21}$ www.suara.com/news/2015/12/01/021900/kejagung-terima-126-surat-penyidikankasus-kebakaran-hutan diakses pada tanggal 10 Desember 2015. 
seimbang dalam penanganannya, meskipun di dalam praktek tidak selalu mudah melakukannya. Berbeda halnya dengan M. Daud Silalahi yang menyebutkan bahwa penegakan hukum lingkungan mencakup penaatan dan penindakan yang meliputi hukum administrasi negara, bidang hukum perdata dan bidang hukum pidana. Undang-Undang No.32 Tahun 2009 tentang Perlindungan dan Pengelolaan Lingkungan Hidup menyediakan tiga macam penegakan hukum lingkungan yaitu penegakan hukum administrasi, perdata dan pidana. Diantara ke tiga bentuk penegakan hukum yang tersedia, penegakan hukum administrasi dianggap sebagai upaya penegakan hukum terpenting. Hal ini karena penegakan hukum administrasi lebih ditunjukan kepada upaya mencegah terjadinya pencemaran dan perusakan lingkungan. Di samping itu, penegakan hukum administrasi juga bertujuan untuk menghukum pelaku pencemaran dan perusakan lingkungan. Penegakan hukum adalah proses dilakukannya upaya tegaknya atau berfungsinya norma-norma hukum secara nyata sebagai pedoman perilaku dalam hubungan-hubungan dalam kehidupan bermasyarakat dan bernegara. Ditinjau dari subyeknya, penegakan hukum dapat dilakukan oleh subyak yang luas dan dapat pula diartikan sebagai upaya penegakan hukum itu melibatkan semua subyek hukum dalam setiap hubungan hukum.menurut subyeknya penegakan hukum dapat diartikan sebagai upaya aparatur penegak hukum tertentu untuk menjamin dan memastikan tegaknya hukum itu dan aparatur penegak hukum 
itu dapat menggunakan daya paksa untuk dalam proses penegakan hukum. ${ }^{22}$

\section{Pengaruh Penegakan Hukum Lingkungan terhadap Pertumbuhan}

\section{Ekonomi di Indonesia.}

Istilah pembangunan seringkali digunakan dalam hal yang sama dengan pengembangan. Sehingga istilah pembangunan dan pengembangan (development) dapat saling dipertukarkan. Namun berbagai kalangan di Indonesia cenderung menggunakan secara khusus istilah pengembangan untuk beberapa hal yang spesifik. Meski demikian, sebenarnya secara umum kedua istilah tersebut diartikan secara tidak berbeda untuk proses-proses yang selama ini secara universal dimaksudkan sebagai pembangunan atau developmet. Ada yang berpendapat bahwa kata "pengembangan" lebih menekankan proses meningkatkan dan memperluas. Dalam pengertian bahwa pengembangan adalah melakukan sesuatu yang tidak dari "nol", atau tidak membuat sesuatu yang sebelumnya tidak ada, melainkan melakukan sesuatu yang sebenarnya sudah ada tapi kualitas dan kuantitasnya ditingkatkan atau diperluas menurut Rustiadi.

Sumitro mendefinisikan pembangunan sebagai "suatu transformasi dalam arti perubahan struktur ekonomi. Perubahan struktur ekonomi diartikan sebagai perubahan dalam struktur ekonomi masyarakat yang meliputi perubahan pada perimbangan keadaan yang melekat pada landasan kegiatan ekonomi dan bentuk

\footnotetext{
${ }^{22}$ Kartono, 2009, Penegakan Hukum Lingkungan Administratif Dalam Undang-Undang Perlindungan dan Pengelolaan Lingkungan Hidup, Jurnal Dinamika Hukum, Vol.09 No. 3, Purwekerto: FH UNSOED, halaman 247-257.
} 
susunan ekonomi. Menurut penulis, pemahaman Sumitro ini terkait dengan pandangan Arthur Lewis tentang pentingnya transformasi struktur ekonomi pertanian ke struktur ekonomi industri dalam upaya menuju pertumbuhan (dalam aspek ini pengertian pertumbuhan asosiatif dengan pembangunan) ekonomi.

Dalam pada itu, Budiman membagi teori pembangunan ke dalam tiga kategori besar yaitu teori modernisasi, dependensi dan pascadependensi. Teori modernisasi menekankan pada faktor manusia dan budayanya yang dinilai sebagai elemen fundamental dalam proses pembangunan. Kategori ini dipelopori orang-orang seperti (a) Harrod-Domar dengan konsep tabungan dan investasi (saving and investation), (b) Weber dengan tesis etika protestan dan semangat kapitalisme (the protestant ethic and the spirit of capitalism), (c) McClelland dengan kebutuhan berprestasi, (d) Rostow dengan lima tahap pertumbuhan ekonomi (the five stage of economics growth), (e) Inkeles dan Smith dengan konsep manusia modern, serta ( $f$ ) Hoselitz dengan konsep faktor-faktor non-ekonominya.

Di lain sisi, Kartasasmita menyatakan, pembangunan adalah "usaha meningkatkan harkat martabat masyarakat yang dalam kondisinya tidak mampu melepaskan diri dari perangkap kemiskinan dan keterbelakangan. Membangun masyarakat berarti memampukan atau memandirikan mereka". Menurut Tjokrowinoto, batasan pembangunan yang nampaknya bebas dari kaitan tata nilai tersebut dalam realitasnya menimbulkan interpretasi-interpretasi yang seringkali secara diametrik bertentangan satu sama lain sehingga 
mudah menimbulkan kesan bahwa realitas pembangunan pada hakikatnya merupakan self project reality.

Secara filosofis, suatu proses pembangunan dapat diartikan sebagai "upaya yang sistematik dan berkesinambungan untuk menciptakan keadaan yang dapat menyediakan berbagai alternatif yang sah bagi pencapaian aspirasi setiap warga yang paling humanistik" menurut Rustiadi. Di lain sisi, UNDP mendefinisikan pembangunan dan khususnya pembangunan manusia sebagai "suatu proses untuk memperluas pilihan-pilihan bagi penduduk (a process of enlarging people's choices). Dalam konsep tersebut, penduduk ditempatkan sebagai tujuan akhir (the ultimate end), bukan alat, cara atau instrumen pembangunan sebagaimana dilihat oleh model formasi modal manusia (human capital formation) sedangkan upaya pembangunan dipandang sebagai sarana untuk mencapai tujuan itu. Menurut Todaro pembangunan merupakan suatu kenyataan fisik sekaligus tekad suatu masyarakat untuk berupaya sekeras mungkin melalui serangkaian kombinasi proses sosial, ekonomi, dan institusional demi mencapai kehidupan yang serba lebih baik. Karena itu, proses pembangunan di semua masyarakat paling tidak harus memiliki tiga tujuan inti, yaitu: pertama, peningkatan ketersediaan serta perluasan distribusi berbagai macam barang kebutuhan hidup yang pokok seperti pangan, sandang, papan, kesehatan dan perlindungan keamanan. Kedua, peningkatan standar hidup yang tidak hanya berupa peningkatan pendapatan, tetapi juga meliputi penambahan penyediaan lapangan kerja, perbaikan kualitas pendidikan, serta peningkatan perhatian atas nilai-nilai kultural dan 
kemanusiaan yang kesemuanya itu tidak hanya untuk memperbaiki kesejahteraan materiil, melainkan juga menumbuhkan harga diri pada pribadi dan bangsa yang bersangkutan. Ketiga, perluasan pilihan-pilihan ekonomis dan sosial bagi setiap individu serta bangsa secara keseluruhan. Pandangan Todaro merupakan pengembangan pemahaman atas pandangan Sen tentang pembangunan. Sen memaknai pembangunan sebagai kebebasan. Pembahasan pandangan pembangunan sebagai kebebasan Sen dibahas dalam sub bab di bawah ini.

Di Indonesia, istilah pembangunan sudah sejak lama menjadi terminologi sehari-hari. Terminologi yang erat kaitannya dengan pembangunan dikenal konsep Delapan Jalur Pemerataan yang merupakan penjabaran dari Trilogi Pembangunan. Syahyuti memberkan pendapat Delapan jalur pemerataan yang dimaksud adalah pemerataan dalam hal: (1) pemenuhan kebutuhan pokok rakyat banyak, berupa pangan, sandang dan perumahan; (2) kesempatan memperoleh pendidikan dan pelayanan kesehatan; (3) pembagian pendapatan; (4) kesempatan kerja; (5) kesempatan berusaha; (6) kesempatan berpartisipasi dalam pembangunan, khususnya bagi generasi muda dan kaum wanita; (7) penyebaran pembangunan; dan (8) kesempatan memperoleh keadilan.

Mengacu pada berbagai definisi pembangunan di atas, maka para ekonom merumuskan ukuran-ukuran keberhasilan pembangunan. Dudleey Seer dalam Todaro merumuskan ukuran-ukuran keberhasilan pembangunan sebagai berikut: a) Tingkat ketimpangan pendapatan; b) Penurunan jumlah kemiskinan; c) Penurunan tingkat 
pengangguran. Ketiga ukuran keberhasilan di atas jika disimak lebih dalam adalah menuju satu sasaran akhir yaitu meningkatkan kesejahteraan masyarakat. Meningkatnya kesejahteraan masyarakat berarti menurunnya kemiskinan. Menurut Sadono Sukirno, pertumbuhan dan pembangunan ekonomi memiliki definisi yang berbeda, yaitu pertumbuhan ekonomi ialah proses kenaikan output perkapita yang terus menerus dalam jangka panjang. Pertumbuhan ekonomi tersebut merupakan salah satu indikator keberhasilan pembangunan. Dengan demikian makin tingginya pertumbuhan ekonomi biasanya makin tinggi pula kesejahteraan masyarakat, meskipun terdapat indikator yang lain yaitu distribusi pendapatan. Sedangkan pembangunan ekonomi ialah usaha meningkatkan pendapatan perkapita dengan jalan mengolah kekuatan ekonomi potensial menjadi ekonomi riil melalui penanaman modal, penggunaan teknologi, penambahan pengetahuan, peningkatan ketrampilan, penambahan kemampuan berorganisasi dan manajemen.

Pembangunan ekonomi didefinisikan dalam beberapa pengertian dengan menggunakan bahasa berbeda oleh para ahli, namun maksunya tetap sama. Menurut Adam Smith pembangunan ekonomi merupakan proses perpaduan antara pertumbuhan penduduk dan kemajuan teknologi. Todaro mengartikan pembangunan sebagai suatu proses multidimensional yang menyangkut perubahanperubahan besar dalam struktur sosial, sikap masyarakat, kelembagaan nasional maupun percepatan pertumbuhan ekonomi, pengurangan ketidakmerataan dan penghapusan dari kemiskinan mutlak. Pembangunan ekonomi menurut Irawan adalah usaha-usaha 
untuk meningkatkan taraf hidup suatu bangsa yang seringkali diukur dengan tinggi rendahnya pendapatan riil perkapita. Prof. Meier mendefinisikan pembangunan ekonomi sebagai proses kenaikan pendapatan riil perkapita dalam suatu jangka waktu yang panjang. Sadono Sukirno mendefinisikan pembangunan ekonomi sebagai suatu proses yang menyebabkan pendapatan perkapita penduduk suatu masyarakat meningkat dalam jangka panjang. Definisi tersebut mengandung pengertian bahwa pembangunan ekonomi merupakan suatu perubahan yang terjadi secara terus-menerus melalui serangkaian kombinasi proses demi mencapai sesuatu yang lebih baik yaitu adanya peningkatan pendapatan perkapita yang terus menerus berlangsung dalam jangka panjang.

Menurut Schumpeter, pembangunan ekonomi bukan merupakan proses yang harmonis atau gradual, tetapi merupakan perubahan yang spontan dan tidak terputus-putus. Pembangunan ekonomi disebabkan oleh perubahan terutama dalam lapangan industri dan perdagangan. Pembangunan ekonomi berkaitan dengan pendapatan perkapita dan pendapatan nasional. Pendapatan perkapita yaitu pendapatan rata-rata penduduk suatu daerah sedangkan pendapatan nasional merupakan nilai produksi barang-barang dan jasa-jasa yang diciptakan dalam suatu perekonomian di dalam masa satu tahun. Pertambahan pendapatan nasional dan pendapatan perkapita dari masa ke masa dapat digunakan untuk mengetahui laju pertumbuhan ekonomi dan juga perkembangan tingkat kesejahteraan masyarakat suatu daerah. Dalam pengertian pembangunan ekonomi yang dijadikan pedoman adalah sebagai suatu proses yang menyebabkan 
pendapatan perkapita penduduk suatu masyarakat meningkat dalam jangka panjang. Sementara itu pertumbuhan ekonomi menurut Prof. Simon Kuznets, adalah kenaikan jangka panjang dalam kemampuan suatu negara untuk menyediakan semakin banyak jenis barangbarang ekonomi kepada penduduknya. Kemampuan ini tumbuh sesuai dengan kemajuan teknologi, dan penyesuaian kelembagaan dan idiologis yang diperlukannya.

Definisi ini mempunyai 3 (tiga) komponen: pertama, pertumbuhan ekonomi suatu bangsa terlihat dari meningkatnya secara terusmenerus persediaan barang; kedua, teknologi maju merupakan faktor dalam pertumbuhan ekonomi yang menentukan derajat pertumbuhan kemampuan dalam penyediaan aneka macam barang kepada penduduk; ketiga, penggunaan teknologi secara luas dan efisien memerlukan adanya penyesuaian di bidang kelembagaan dan ideologi sehingga inovasi yang dihasilkan oleh ilmu pengetahuan umat manusia dapat dimanfaatkan secara tepat. Dengan bahasa lain, Boediono menyebutkan pertumbuhan ekonomi adalah proses kenaikan output dalam jangka panjang. Pengertian tersebut mencakup tiga aspek, yaitu proses, output perkapita, dan jangka panjang. Jadi, dengan bukan bermaksud 'menggurui', pertumbuhan ekonomi merupakan suatu proses, bukan gambaran ekonomi atau hasil pada saat itu. Boediono menyebutkan secara lebih lanjut bahwa Pertumbuhan ekonomi juga berkaitan dengan kenaikan "output perkapita". Dalam pengertian ini teori tersebut harus mencakup teori mengenai pertumbuhan GDP dan teori mengenai pertumbuhan penduduk. Sebab hanya apabila kedua aspek tersebut 
dijelaskan, maka perkembangan output perkapita bisa dijelaskan. Kemudian aspek yang ketiga adalah pertumbuhan ekonomi dalam perspektif jangka panjang, yaitu apabila selama jangka waktu yang cukup panjang tersebut output perkapita menunjukkan kecenderungan yang meningkat.

Pertumbuhan bisa saja diartikan berbeda oleh satu orang dengan orang lain, daerah yang satu dengan daerah lain, negara satu dengan negara lain. Penting bagi kita untuk dapat memiliki definisi yang sama dalam mengartikan pertumbuhan. Secara tradisional pertumbuhan memiliki peningkatan terus menerus pada Gross Domestic Product atau Produk Domestik Bruto suatu negara. Untuk daerah, makna pertumbuhan yang tradisonal difokuskan pada peningkatan Produk Domestik Regional Bruto suatu provinsi, kabupaten atau kota. Pendapat mengenai definisi pertumbuhan ekonomi menurut para ahli adalah Simon Kuznet, mendefinisikan pertumbuhan ekonomi sebagai kenaikan jangka panjang dalam kemampuan suatu negara untuk menyediakan semakin banyak jenis barang-barang ekonomi kepada penduduknya, kemampuan ini tumbuh sesuai dengan kemajuan teknologinya dan penyesuaian kelembagaan dan ideologis yang diperlukan. M. P. Todaro mendefinisikan pertumbuhan ekonomi sebagai suatu proses yang mantap dimana kapasitas produksi dari suatu perekonomian meningkat sepanjang waktu untuk menghasilkan tingkat pendapatan nasional yang semakin besar. Menurut Budiono, pertumbuhan ekonomi adalah suatu proses pertumbuhan output perkapita jangka panjang yang terjadi apabila ada kecenderungan output perkapita untuk naik yang bersumber 
dari proses intern perekonomian tersebut kekuatan yang berada dalam perekonomian itu sendiri, bukan berasal dari luar dan bersifat sementara. Atau dengan kata lain bersifat self generating, yang berarti bahwa proses pertumbuhan itu sendiri menghasilkan suatu kekuatan atau momentum bagi kelanjutan pertumbuhan tersebut dalam periode-periode selanjutnya. Sadono Sukirno berpendapat bahwa pertumbuhan ekonomi merupakan perubahan tingkat kegiatan ekonomi yang berlaku dari tahun ke tahun. Sehingga untuk mengetahuinya harus diadakan perbandingan pendapatan naional dari tahun ke tahun, yang dikenal dengan laju pertumbuhan ekonomi ${ }^{23}$.

Terdapat tiga komponen pokok dalam definisi pertumbuhan ekonomi tersebut tersebut, yaitu:

a. Kenaikan output secara berkesinambungan adalah manifestasi daripertumbuhan ekonomi sedangkan kemampuan menyediakan berbagai jenis barang merupakan tanda kematangan ekonomi (economic maturity) pada negara bersangkutan.

b. Perkembangan ilmu pengetahuan dan teknologi yang berkesinambungan dimana pemerintah berperan dalam investasi bidang pendidikan.

c. Mewujudkan potensi pertumbuhan yang terkandung dalam kemajuan teknologi dilakukan penyesuaian kelembagaan, sikap, dan ideologi. Sehingga secara sosial dan ekonomi terjadi pertumbuhan yang seiring.

${ }^{23}$ Sadono Sukirno, Ekonomi Pembangunan, Penerbit FEUI, 1985 
Menurut pandangan para ekonom klasik (Adam Smith, David Ricardo, Thomas Robert Malthus dan John Stuart Mill), maupun para ekonom neoklasik (Robert Sollow dan Trevor Swan), pada dasarnya ada empat faktor yang mempengaruhi pertumbuhan ekonomi yaitu' ${ }^{24}$ :

a. Jumlah penduduk;

b. Jumlah stok barang modal;

c. Luas tanah dan kekayaan alam, dan

d. Tingkat teknologi yang digunakan.

Suatu perekonomian dikatakan mengalami pertumbuhan atau berkembang apabila tingkat kegiatan ekonominya lebih tinggi daripada apa yang dicapai pada masa sebelumnya. Kepastian Hukum dan Kepastian Berusaha Dinobatkannya Indonesia sebagai negara tujuan investasi ke-3 di Asia setelah Cina dan India oleh Asia Business Outlook yang dikeluarkan Economist Corporate Network awal tahun ini, belum tentu akan menarik perhatian investor, baik lokal maupun asing. Pasalnya, PMA lebih mengharapkan adanya kepastian hukum yang baik di negeri ini guna mendukung kepastian usaha. Ketua Asosiasi Pengusaha Indonesia (Apindo), Sofyan Wanandi, mengatakan kepastian hukum adalah faktor utama yang diperhatikan pengusaha ketika ingin berinvestasi. Sayangnya, hal itu tidak terlihat di Indonesia. Di indonesia banyak peraturan yang tidak jelas membuat pengusaha sulit menghitung cost, banyak investor asing yang ingin berinvestasi di Indonesia. Namun, ketidakpastian hukum yang ada membuat pengusaha mengurungkan niat untuk menanamkan modal. Apalagi, sambungnya, hampir semua

\footnotetext{
${ }^{24}$ Mudrajad Kuncoro, "Otonomi dan Pembangunan Daerah: Reformasi, Perencanaan, Strategi, dan Peluang ", Penerbit Erlangga, Jakarta, 2004
} 
regulasi berubah jika ada perubahan di tubuh pemerintahan. Peradilan di Indonesia sudah terkenal dengan jual beli hukum sehingga investor baik lokal maupun asing sudah bekerja sesuai dengan regulasi yang berlaku. Hal lain yang diperhatikan pengusaha ketika ingin berinvestasi adalah masalah kemanan dan infrastruktur. Berdasarkan dari hasil penelitian Pusat Kajian Fakultas Ekonomi Universitas Indonesia, dari 120 responden PMA, mayoritas lebih menginginkan kepastian hukum dibanding mendapatkan insentif dari pemerintah. Pakar Hukum Keuangan Negara Universitas Indonesia (UI), Dian Puji Simatupang, dalam keterangan tertulisnya mengatakan sebanyak 89 persen investor menginginkan produk hukum yang lebih baik untuk menjamin kelanjutan investasi di sini Beberapa kasus ketidakpastian hukum yang dikemukanan oleh PMA antara lain mengenai dimenangkannya gugatan Renaissance Capital Management Investment Pte Ltd terhadap Merrill Lynch International Bank Ltd. MA telah memutuskan Renaissance yang dimiliki Prem Harjani berhak mendapat ganti sebesar Rp 251 miliar. Padahal sebelumnya di Pengadilan Tinggi Singapura, telah memutuskan bahwa Prem Harjani telah melakukan penipuan dan Renaissance telah mengakui hutangnya kepada Merrill Lynch. Tak heran jika banyak kasus PMA yang lebih memilih menghindari berperkara di pengadilan Indonesia. Seperti kasus yang dialami Medley Opportunity Fund di tahun 2012. Ketika berperkara dengan pengusaha lokal, perusahaan asal AS ini lebih memilih pengadilan di Inggris dan Singapura. Begitupun dengan Churchill Mining, perusahaan asal Inggris, tahun lalu juga memilih mengajukan 
gugatan ke International Centre for Settlement of Investment Disputes (ICSID) di Washington, AS, saat bersengketa dengan pemerintah RI dalam kasus pencabutan ijin tambangnya. Dia menambahkan, ada tiga hal yang menjadi perhatian utama $P M A^{25}$. Pertama, produk hukum yang menciptakan kebingungan karena multitafsir. Kedua, sistem hukum peradilan di mana Indonesia menganut pada hukum Belanda. Namun, ketika ada perkara, banyak menggunakan dasar hukum dan berubah-ubah. Sedangkan yang ketiga yaitu Risiko Politik. Setiap pergantian pejabat maka kebijakan yang dibuat juga mengalami perubahan sehingga membingungkan investor. Sehingga jika kondisi ini terus berlangsung, PMA belum bisa memastikan keberlangsungan investasinya di Indonesia. Menurut Adi Sulistyono memberikan berpendapat mengenai konsep pembangunan pembangunan hukum ekonomi berkelanjutan (sustainable economic law development), selain melakukan pembangunan hukum harus memberdayakan daya dukung aspek yang lainnya ${ }^{26}$ yaitu terkait dengan Mekanisme penyelesaian sengketa yang berwibawa dan efisien; dan Komitmen presiden dan wakil presiden, yang aktivitasnya dilakukan secara mengait, bersama-sama, dan terus menerus dan saling mendukung sehingga adanya kepastian hukum dalam berinvestasi maka pertumbuhan ekonomi akan bergerak kearah positif.

\footnotetext{
${ }^{25}$ www.chaidirritonga.com/new/beberapa-faktor-pendorong-pertumbuhan-ekonomiindonesia diakses pada 02 Desember 2015

${ }^{26}$ Adi Sulistyono dan Muhammad Rastamji, 2009, Hukum Ekonomi Sebagai Panglima, Masmedia Buana Pustaka, Sidoarjo, halaman 75
} 


\section{E. Penutup}

\section{Kesimpulan}

Berdasarkan pembahasan tersebut di atas maka dapat diambil kesimpulan sebagai berikut :

a. Penegakan hukum lingkungan di Indonesia pada studi kasus kebakaran hutan yaitu Penegakan hukum lingkungan di Indonesia di lakukan oleh pemerintah dengan tegas yaitu terbukti Kejagung Terima 126 Surat Penyidikan Kasus Kebakaran Hutan, Kejaksaan Agung sampai sekarang sudah menerima 126 Surat Pemberitahuan Dimulainya Penyidikan (SPDP) kasus kebakaran hutan dan lahan di seluruh Indonesia dari kepolisian, ini menandakan bahwa kepastian hukum, kemanfaatan dan keadilan harus tercapai sebagai tujuan dari hukum itu sendiri. Undangundang Nomor 32 Tahun 2009 tentang Perlindungan dan Pengelolaan Lingkungan Hidup mengatur sanksi kepada pihak yang terbukti melanggar yaitu penegakan hukum dibidang lingkungan hidup dapat diklasifikasikan kedalam 3 (tiga) kategori yaitu : 1). Penegakan hukum Lingkungan dalam kaitannya dengan Hukum Administrasi / Tata Usaha Negara, 2). Penegakan Hukum Lingkungan dalam kaitannya dengan Hukum Perdata, 3). Penegakan Hukum Lingkungan dalam kaitannya dengan Hukum Pidana. Pada Pasal 69 ayat (1) huruf H Undang-undang Nomor 32 tahun 2009 tentang Perlindungan dan Pengelolaan Lingkungan Hidup memuat tentang larangan melakukan pembukaan lahan dengan cara membakar yaitu : (1) Setiap orang dilarang: $h$. melakukan pembukaan lahan dengan cara membakar; Pasal 108 
Undang-undang Nomor 32 tahun 2009 tentang Perlindungan dan Pengelolaan Lingkungan Hidup memuat tentang sanksi bagi yang melanggar yaitu : Setiap orang yang melakukan pembakaran lahan sebagaimana dimaksud dalam Pasal 69 ayat (1) huruf $h$, dipidana dengan pidana penjara paling singkat 3 (tiga) tahun dan paling lama 10 (sepuluh) tahun dan denda paling sedikit Rp3.000.000.000,00 (tiga miliar rupiah) dan paling banyak Rp10.000.000.000,00 (sepuluh miliar rupiah)

b. Analisis pengaruh penegakan hukum lingkungan terhadap pertumbuhan ekonomi di Indonesia yaitu :

1) Produk hukum yang menciptakan kebingungan karena multitafsir sehingga tidak ada acuan yang jelas.

2) Sistem hukum peradilan di mana Indonesia menganut pada hukum Belanda. Namun, ketika ada perkara, banyak menggunakan dasar hukum dan berubah-ubah. Sedangkan yang

3) Risiko Politik. Setiap pergantian pejabat maka kebijakan yang dibuat juga mengalami perubahan sehingga membingungkan investor. PMA lebih mengharapkan adanya kepastian hukum yang baik di negeri ini guna mendukung kepastian usaha karena kepastian hukum merupakan salah satu faktor dalam pertumbuhan ekonomi.

Pertumbuhan ekonomi suatu negara tergantung sumber daya dan tata kelolanya,sesuai dengan pandangan para ekonom klasik (Adam Smith, David Ricardo, Thomas Robert Malthus dan John Stuart Mill), maupun para ekonom neoklasik (Robert Sollow 
dan Trevor Swan), pada dasarnya ada empat faktor yang mempengaruhi pertumbuhan ekonomi yaitu :

a) Jumlah penduduk,

b) Jumlah stok barang modal,

c) Luas tanah dan kekayaan alam, dan

d) Tingkat teknologi yang digunakan.

Suatu perekonomian dikatakan mengalami pertumbuhan atau berkembang apabila tingkat kegiatan ekonominya lebih tinggi daripada apa yang dicapai pada masa sebelumnya.

\section{Rekomendasi}

Berdasarkan analisa dari Penegakan Hukum Lingkungan Dan Pengaruhnya terhadap Pertumbuhan Ekonomi Di Indonesia (Studi Kasus Kebakaran Hutan) ini, maka dapat direkomendasikan bahwa penegakan hukum yang konsisten serta tegas dan berdasarkan peraturan perundangan yang berlaku harus terus dilakukan untuk menciptakan kepastian hukum bagi investor sehingga para calon investor melihat Indonesia aman dan terjamin sebagai tempat investasi sehingga mendorong pertumbuhan ekonomi.

Kepastian hukum, khususnya subtansi peraturan perundangundangan khususnya penghapusan Pasal 69 UU PPLH ayat 2 (dua) sehingga tidak bertentangan dengan pasal lainnya, adapun pasalnya yaitu :

a) Setiap orang dilarang: h. melakukan pembukaan lahan dengan cara membakar:

b) Ketentuan sebagaimana dimaksud pada ayat (1) huruf $h$ memperhatikan dengan sungguhsungguh kearifan lokal di daerah masing-masing. 
Penjelasan Pasal 69 Ayat (2) UUPPLH "Kearifan lokal yang dimaksud dalam ketentuan ini adalah melakukan pembakaran lahan dengan luas lahan maksimal 2 hektare per kepala keluarga untuk ditanami tanaman jenis varietas lokal dan dikelilingi oleh sekat bakar sebagai pencegah penjalaran api ke wilayah sekelilingnya".

\section{DAFTAR PUSTAKA}

Adi Sulistyono dan Muhammad Rastamji, Hukum Ekonomi Sebagai Panglima, Masmedia Buana Pustaka, Sidoarjo, 2009.

C.F.G. Sunaryati Hartono, Politik Hukum Menuju Satu Sistem Hukum Nasional, Bandung: Alumni, 1991.

Gatot. P. Soemartono. Hukum Lingkungan Indonesia. Jakarta. Sinar Grafika. 2005.

Kartono, Penegakan Hukum Lingkungan Administratif Dalam UndangUndang Perlindungan dan Pengelolaan Lingkungan Hidup, Jurnal Dinamika Hukum, Vol.09 No. 3, Purwekerto : FH UNSOED, 2009.

Lawrence M. Friedman, American Law: An invalueable guide to the many faces of the law, and how it affects our daily lives, New York: W.W. Norton \& Company, 1984.

Lili Rasjidi, Filsafat Hukum Apakah Hukum Itu?, Bandung: Remaja Rosdakarya, 1991.

Max Weber dalam A.A.G. Peters dan Koesriani Siswosoebroto, Hukum dan Perkembangan Sosial (Buku I), Jakarta: Sinar Harapan, 1988.

Mochtar Kusumaatmadja, Fungsi dan Perkembangan Hukum dalam Pembangunan Nasional, Bandung: Binacipta, 1986.

Nana Sudiana dan Hasmana Soewandita, Pola Konservasi Sumber Daya 
Air di Daerah Aliran Sungai Siak, Jurnal Alami Vol. 12 Nomor 1, 2007.

Ridwan HR. Hukum administrasi Negara. PT.RajaGrafindo. Jakarta. 2006.

Roeslan Saleh, Penjabaran Pancasila dan UUD 1945 Dalam Perundangundangan, Jakarta: Bina Aksara, 1979.

Satjipto Rahardjo, Masalah Penegakan Hukum, Bandung: Sinar Baru, 1983.

Siti Kotijah, Implementasi Prinsip-prinsip Kehutanan dalam Rangka Konservasi Kehutanan: studi kasus di Jawa Timur, Jurnal Magister Hukum, Vol. 1 Nomor 2, Surabaya : Program Studi Magister Ilmu Hukum, Universitas Wisnuwardhana, 2010.

Soerjono Soekanto, Penegakan Hukum, Jakarta: BPHN \& Binacipta, 1983.

Soerjono Soekanto. Faktor-faktor yang mempengaruhi Penegakan Hukum. Rajawali Press. Jakarta,1983.

Suwari Akhmaddhian, 2013. Peran Pemerintah Daerah Dalam Mewujudkan Hutan Konservasi Berdasarkan Undang-undang Nomor 41 tahun 199 tentang Kehutanan (Studi di Kabupaten Kuningan), Jurnal Dinamika Hukum Vol.13 Nomor 3 September 2013, Purwokerto: FH Universitas Jenderal Soedirman.

www.chaidirritonga.com/new/beberapa-faktor-pendorongpertumbuhan-ekonomi-indonesia diakses pada 02 Desember 2015 www.suara.com/news/2015/12/01/021900/kejagung-terima-126surat-penyidikan-kasus-kebakaran-hutan diakses pada tanggal 10 Desember 2015. 